\title{
MENGKAJI PR POLITIK: SEBUAH TINJAUAN TEORITIS DAN EMPIRIS
}

\author{
Inri Inggrit Indrayani \\ Program Studi Ilmu Komunikasi, Fakultasa Ilmu Komunikasi, Universitas Kristen Petra \\ Jalan Siwalankerto 121-131, Surabaya 60236, INDONESIA \\ E-mail: inri.inggrit@petra.ac.id
}

\begin{abstract}
ABSTRAK
Dinamika politik yang diikuti dengan gelombang demokratisasi menguatkan eksistensi Public Relations (PR) sebagai ubiquitous entity. Pengaruh antara PR Politik dengan PR dan Komunikasi Politik berimplikasi pada pemahaman yang tidak tepat mengenai posisi PR Politik dalam kajian PR. PR Politik yang dikenal dengan istilah spin doctors menunjukkan persepsi yang negatif, yakni lebih menekankan model PR propagandis daripada two way symmetrical communication. Sekalipun secara empiris, model PR propagandis tetap dibutuhkan namun pendekatan two way symmetrical communication merupakan tantangan yang harus dijawab oleh aktor politik terkait demokratisasi. Tulisan ini mendeskripsikan PR Politik baik secara teoritis dan empiris dalam mengidentifikasikan dirinya sebagai bagian dalam kajian dalam PR. Sekaligus menentukan titik pembeda dengan komunikasi politik yakni penekanan terhadap pentingnya hubungan dan fungsi manajemen dalam mencapai tujuan politis daripada sekedar menyampaikan pesan politik saja.
\end{abstract}

Kata kunci: PR politik; komunikasi politik; mutual understanding; propagandis; two way symmetrical communikasi.

\begin{abstract}
Political dynamics that is followed by a wave of democratization reinforcing the existence of the Public Relations (PR) as a ubiquitous entity. The interplay between Political PR with PR itself and Political Communication causes a misleading understanding about the domain of Political PR in the PR studies. Political PR is known as spin doctors refers to a negative perception, which emphasizes the model of PR propagandists rather than two way symmetrical communication. Although empirically, propagandist $P R$ is still needed nevertheless the approach of two way symmetrical communication is more challenging that must be conducted by political actors in an account of democratization. This paper aims to convey a description about Political PR both theoretically and empirically as well as to distinguish Political PR and political communication. Political PR emphasises on the importance of relationship and management function in achieving political objectives instead of communicating political messages only as political communication do.
\end{abstract}

Keywords: Political PR; political communication; mutual understanding; propagandist; two way symmetrical communication.

\section{PENDAHULUAN}

Terminologi Public Relations atau PR seringkali dikaitkan dengan aktivitas pembangunan citra dan reputasi khususnya dalam korporasi yang bergerak di business domain. Salah satu perspektif yang dikenal dalam anatomi PR ialah pembedaan antara corporate dan marketing PR. Pembedaan ini terkait dengan fungsi yang diberikan organisasi kepada departemen PR. Apa prioritas serta tujuan organisasi ? Bila PR berada dalam perusahaan-perusahaan yang memiliki budaya market driven, maka dominasi marketing public relations (MPR) menjadi dibutuhkan. Sebaliknya apabila PR didesain untuk domain korporasi maka CPR menjadi lebih utama. Adapun harapan lain yang sering muncul dari manajemen organisasi adalah sinergi peran antara CPR dan MPR sehingga mampu mendukung pencapaian objective perusahaan. (Wasesa \& Mcnamara, 2013, p.30)

Kotler (dalam Moloney, 2000) menegaskan bahwa MPR merupakan representasi momen atau kesempatan bagi perusahaan untuk memperoleh kembali pangsa suara dalam masyarakat di era informasi ini. MPR tidak sekedar 'noise' namun juga alat strategis untuk bersuara lebih efektif dalam merebut hati target pasar. Di era informasi seperti saat ini, pesan lebih efektif apabila ditampilkan sebagai produk jurnalistik atau berita daripada iklan. Perusahaan juga akan memperoleh perhatian serta penghargaan dari publik apabila mereka terlibat dalam kegiatan yang memberikan sumbangsih bagi kepentingan publik secara luas. 
Edward Bernays, Bapak PR modern, dalam tulisannya yang bertajuk "Manipulating Public Opinion" (2003) memaparkan bahwa teknik pengukuran maupun pencatatan mengenai relasi antar manusia belum sesempurna teknik pengukuran dalam bidang ilmu pasti. Belum adanya parameter yang pasti untuk mengetahui bagaimana manipulasi dilakukan untuk mempengaruhi opini publik. Bernays menyinggung bahwa manipulasi ini dalam tingkatan lebih lanjut akan memainkan aspek psikologis publik dengan memberikan serangkaian data ilmiah yang mendukung aksi propagandanya sehingga pembentukan opini publik tercapai. Serangkaian manipulasi itu bisa dilakukan melalui iklan sebagai salah satu produk propaganda maupun melalui teknik-teknik PR.

Bagaimanakah peran dan eksistensi PR di luar ranah korporat? Tulisan ini selanjutnya mencoba untuk menelaah serta mengkaji PR dalam konteks politik atau secara terminologi dikenal dengan Political PR. Tak dapat dipungkiri bahwa secara empirik, PR dan politik menjadi sebuah entitas yang saling bertautan. Praktik-praktik kePR-an bukan saja ditemukan di negara-negara maju namun juga menjadi euphoria bagi pelaksanaan pemilu di negara-negara berkembang. Aktor politik, organisasi politik maupun proses politik menjadi semacam ruang bagi PR untuk membuktikan diri sebagai ubiquitos entity. Dinamika politik global kontemporer, nyaris, tidak ada aktivitas politik tanpa aktivitas PR.

PR Politik sebagai sebuah kajian keilmuan public relations belum banyak dikembangkan khususnya di negara-negara dunia ketiga, dimana peran dan fungsi PR secara khusus hanya dikaitkan dengan aktivitas promosi serta identik sebagai tenaga make up perusahaan. Dalam kenyataannya, PR Politik juga seringkali diidentifikasikan dengan komunikasi politik. Sekalipun, PR Politik lahir dari dominasi bidang studi Ilmu Komunikasi serta Ilmu Politik namun dirasakan signifikan untuk membentuk sekaligus mendefinisikan PR Politik sebagai sebuah kajian baru. Sekalipun secara empirik, PR Politik telah berkembang sebelum abad pertama. Pada bagian selanjutnya dalam tulisan ini akan melakukan eksplorasi baik secara teoritis maupun praktis mengenai PR Politik.

\section{PEMBAHASAN}

\subsection{PR Politik: Menilik Sejarah dan Perkembang- annya}

Sekalipun PR Politik secara teoritik merupakan kajian baru dalam Public Relations namun secara praktis PR
Politik disinyalisir telah ada sejak abad ke 64 sebelum masehi. Peristiwa yang menandai asal mula PR Politik ialah pada saat kerajaan Roma memilih seorang konsul dimana salah seorang kandidatnya ialah Marcus Tullius Cicero yang berasal dari luarn kota Roma dan bukan dari kalangan bangsawan. Cicero berhasil menarik perhatian publik baik dari kalangan elit sosial maupun grass root dan akhirnya memenangkan pemilihan tersebut, mengalahkan Antonius dan Catiline. Ialah saudara laki-laki Marcus Cicero yakni Quintus Tullius Cicero, seorang spin doctor dan aktor di balik layar yang sukses menggiring publik memilih Marcus menjadi konsul kerajaan Romawi.

Melalui tulisannya, Quintus menggagas agar Maucus memenangkan hati publik antara lain dengan menanamkan harapan ke benak publik dan memegang komitmen pada publik serta memperlakukan lawan politik sebagai rekan kerja. Tulisan Quintus yang ditujukan kepada Marcus tersebut disebarkan dalam bentuk pamflet, dikenal dengan nama Commentariolum Petitionis yang saat ini menjadi little handbook of electoring. Sekalipun Commentariolum Petitionis bersifat propagandis namun tulisan inilah yang menginisiasi kegiatan publikasi dalam aktivitas politik seperti kampanye dan pemilihan politik pada masa itu. (Stromback \& Kiousis, 2013)

Kehadiran PR Politik kemudian banyak ditemukan di negara-negara Barat sekitar tahun 1970-an ketika opini publik menjadi krusial dan media menjadi salah satu aktor dalam kontestasi politik. Aktivitasnya memang lebih banyak fokus pada pengelolaan media sehingga memperoleh coverage besar-besaran di media serta bagaimana meminimalisir pemberitaan negatif media. Hal inilah yang menjadi penekanan spin doctor melalui news management yang sarat dengan manipulasi serta indoktrinisasi. PR Politik modern berkembang melalui penggunakan teknik kampanye pemasaran dan komersial untuk membangun hubungan dengan publiknya. Aksi propaganda ini kemudian dipandang tidak lagi relevan dengan dinamika demokratisasi, memunculkan PR Politik yang lebih menekankan two way communication serta mutual understanding.

Di era politik yang didominasi opini publik, pengelolaan image dan kemampuan representasi menjadi tak terelakkan. Aktor politik dituntut untuk mampu melakukan persuasi dan engagement dalam menarik partisipasi publik. Model two ways symmetric communication dipandang sesuai dan mengakomodir nilai-nilai demokrasi ketika publik terlibat dalam 
proses pengambilan keputusan. Model ini menjanjikan adanya hubungan yang setara, egaliter dan interaktif antara aktor politik dengan publiknya. Sosok Jokowi dalam kontestasi politik di Indonesia merupakan representasi bagi perubahan budaya politik Indonesia. Dalam perspektif PR, Jokowi dengan komunikasi blusukannya merupakan representasi model two ways symmetrical communication. Tokoh ini berhasil melakukan pendekatan PR guna menjawab tantangan politik.

Masalah-masalah yang terkait dengan implementasi kebijakan publik dapat diatasi melalui dialog antara pemimpin dengan publik terkait. Salah satu yang menjadi andalan Jokowi sebagai pemimpin politik ialah diplomasi makan siang. Makan siang bersama menjadi instrumen bagi pemimpin politik untuk menggali dan melakukan inventarisasi ekspektasi publik.

McNair (2011) mengidentifikasikan terdapat empat jenis aktivitas PR Politik yaitu: Pertama, melakukan manajemen media. Manajemen media merupakan kegiatan-kegiatan yang sengaja dirancang untuk menjawab kebutuhan dan tuntutan media. Dalam konteks ini, PR Politik memaksimalkan akses serta meningkatkan pemberitaan politisi di media tanpa mengeluarkan biaya.

Kedua, PR Politik melakukan tinjauan mengenai pengelolaan citra (image management). Di satu sisi, pengelolan citra ditujukan untuk citra pribadi politisi atau individu. Citra ini harus dibentuk dan disesuaikan dengan tujuan organisasi, di sisi lain, pengelolaan juga dilakukan pada citra organisasi politik.

Ketiga, PR Politik seharusnya mengembangkan komunikasi internal organisasi. Kegiatan ini meliputi menyiapkan saluran komunikasi. Sama halnya yang dilakukan perusahaan modern saat ini yakni rutin mendukung komunikasi internalnya guna memaksimalkan efisiensi organisasi. Demikian pula dengan partai politik, harus mengembangkan struktur komunikasi internal yang efektif.

Terakhir, kegiatan manajemen informasi. Di era informasi ini, dibutuhkan pengelolaan pesan sehingga publik memperoleh informasi yang memadai mengenai aktor politik dan kebijakannya. Informasi adalah senjata ampuh dalam politik guna membangun opini publik serta menyebarkan pengaruh.

Sekalipun PR Politik merupakan termasuk dalam anatomi PR namun Stromback dan Kiousis (2013, p.
4) mengidentifikasikan beberapa perbedaan antara political public relations dengan public relations secara umum, yakni sebagai berikut:

a. Political public relations meliputi seluruh aktivitas-aktivitas public relations yang dilakukan oleh organisasi dan individu untuk tujuan politik, termasuk partai politik dan kandidatnya, sektorsektor pemerintah dan publik, serikat pekerja, bisnis komersial, kelompok kepentingan, dan organisasi non profit yang berusaha mempengaruhi proses atau hasil dalam politik.

b. Political public relations tidak saja berpusat pada aspek komunikasi semata namun juga membutuhkan aksi atau tindakan. Seorang aktor politik yang lihai bermain citra tidak akan memperoleh dukungan publik dalam periode waktu yang panjang apabila representasi tidak berbanding lurus dengan realitasnya yang terbentuk.

c. Political public relations menekankan pentingnya relationship setara dengan reputasi. Reputasi bukan outcome atau dampak dari kinerjanya. Relationship dan reputasi bekerja secara paralel dalam PR Politik.

d. Political public relations dalam konteks tertentu membutuhkan penerapan model tradisional PR seperti publicity dan public information sekalipun dipandang tidak ideal.

PR Politik tidak sekedar mengenai ada atau tidaknya divisi maupun departemen PR yang harus dimiliki oleh aktor politik. Bukan pula konsultan komunikasi yang tersedia pada saat menjelang pemilihan umum. PR Politik lebih banyak menuntut adanya karakter dan kapasitas aktor politik menguasai kebutuhan publik serta membangun sinergi harmonis dengan para stakeholders. Sekalipun strategi, teknik serta taktis PR dibutuhkan namun integritas aktor politik menjadi core business dalam proses keberlangsungan politik.

Penempatan PR juga diidentifikasikan secara berbeda oleh Stromback dan Kiousis (2013, pp. 4-6) apabila ditinjau dari domain dimana PR tersebut berada. Mereka menjelaskan sepuluh aspek perbedaan antara konteks politik dengan konteks korporat:

a. Politik selalu berhadapan dengan pertanyaanpertanyaan normatif yang berkaitan dengan kepentingan orang banyak. Hal ini berangkat dari fakta bahwa politik bersentuhan dengan otoritas pembuatan keputusan yang mempengaruhi kehidupan masyarakat, baik secara langsung maupun tidak langsung. Pembuat kebijakan demokratis dan semua pihak yang bekerja di pemerintahan dan sektor publik harus selalu 
mempertimbangkan kepentingan umum. Hal ini berbeda dengan ranah korporat dimana pertimbangan akan kepentingan publik bersifat opsional atau tidak wajib.

b. Jumlah publik dan pemangku kepentingan dalam politik lebih besar dibandingkan jumlah publik dalam konteks korporat, karena semua orang atau warga negara dapat termasuk sebagai pemangku kepentingan dalam politik.

c. Jumlah regulasi dan tingkat transparansi dalam politik lebih besar dibandingkan dalam korporat.

d. Mata uang utama dalam bisnis ialah kapital atau modal, akan tetapi mata uang utama dalam politik adalah ide dan kekuasaan sehingga produk yang dihasilkan dalam politik lebih bersifat intangible. Namun, hubungan antara organisasi atau aktor politik dengan produk politiknya lebih kuat daripada hubungan antara produk atau jasa dalam bisnis.

e. Proses politik pada akhirnya menentukan siapa yang menang dan kalah. Misalnya dalam pemilihan umum, kemenangan seseorang berarti kekalahan yang lain. Dalam hal ini kompromi mungkin saja terjadi, namun tidak semua orang bisa mendapatkan hasil kebijakan seperti yang diinginkan. Serangkaian kebijakan yang diterima berarti penolakan serangkaian kebijakan yang lain.

f. Organisasi dan aktor politik lebih banyak bergantung pada media berita dan pemberitaannya dibandingkan sektor bisnis komersial. Organisasi politik tidak dapat mengontrol komunikasi mereka bagaimana mereka dan kepentingan yang mereka wakili direpresentasikan kepada publik yang berbeda-beda dan berjumlah besar. Oleh karena itu, organisasi politik membutuhkan media massa dan para jurnalisnya sebagai media komunikasi serta watch dog penjaga yang bersikap kritis terhadap pemegang kekuasaan politik.

g. Tingkatan konflik dalam politik lebih tinggi dibandingkan dalam konteks korporat. Politik berkaitan dengan pertarungan serta pertentangan ide-ide, wacana dan kekuasaan. Proses politik akan menghasilkan pihak yang menang dan yang kalah. Keputusan politik juga memiliki implikasi sejumlah besar pemangku kepentingan dan seluruh bagian masyarakat. Tingkat ketajaman konflik juga dipengaruhi oleh keterampilan mempengaruhi media mengingat media memiliki kecenderungan yang kuat untuk lebih fokus pada konflik politik.

h. Manajemen dan komunikasi krisis dalam politik berbeda dengan konteks korporat. Hal ini karena pihak oposisi dan media dapat berkepentingan memunculkan persepsi mengenai krisis dalam politik dan siapa yang bertanggung jawab terhadap krisis tersebut. Maka, krisis dalam konteks politik lebih bersifat sebagai persepsi daripada kondisi objektif yang sebenarnya.

i. Organisasi politik bergantung lebih banyak pada anggota, aktivis, dan relawan daripada organisasiorganisasi komersial. Karyawan yang dibayar memiliki peran yang lebih kecil dalam organisasi politik, dibandingkan dalam konteks korporat. Organisasi politik lebih banyak mengandalkan relawan dan anggotanya, sehingga organisasi politik memiliki kebutuhan yang lebih besar untuk merekrut, mengorganisir dan memobilisasi relawan dan pendukungnya.

j. Ukuran kesuksesan dan "keputusan membeli" dalam konteks politik dan korporat sangat berbeda. Dalam konteks korporat, kesuksesan diukur berdasarkan indikator finansial, seperti penjualan, pangsa pasar, harga saham dan profit. Dalam konteks politik, ukuran objektif dalam kesuksesan hanya dapat dilihat saat hari pemilihan umum, saat aktor politik berhasil mengumpulkan jumlah suara, terlegitimasi dan terimplementasinya keputusan politiknya.

\subsection{Perbedaan PR Politik dengan Komunikasi Politik}

Persimpangan antara PR Politik dan Komunikasi Politik seringkali menjadi kabur ketika ditautkan dengan terminologi politik. Apakah PR Politik merupakan bagian dari Komunikasi Politik ? Ataukah keduanya saling beririsan ? Pada bagian ini, penulis akan memapaparkan mengenai perbedaan PR Politik dan Komunikasi Politik.

Komunikasi politik dalam kajian politik, dapat dipahami sebagai upaya-upaya pembentukan kesepakatan. Misalnya, kesepakatan menyangkut bagaimana pembagian sumber daya kekuasaan (power sharing) atau bagaimana kesepakatan tersebut dibuat. Sementara komunikasi politik dalam kajian komunikasi dipahami sebagai pesan bercirikan politik untuk mempengaruhi pihak lain dalam pencapaian tujuan yang direncanakan. Dengan demikian, yang pertama, fokus pada aktivitas politik, sementara yang kedua, fokus pada pesan yang politis. (Heryanto \& Rumaru, 2013, p. 2)

Denton dan Woodward (dalam McNair, 2013) mengungkapkan bahwa komunikasi politik merupakan diskusi yang semata-mata membahas mengenai alokasi sumber daya yang tersedia, menentukan otoritas resmi yang menyangkut siapa yang diberi 
kekuasaan untuk membuat produk hukum, siapa berperan sebagai legislatif maupun eksekutif. Komunikasi politik juga menyangkut mengenai pengaturan sanksi maupun reward negara. Dalam karyanya yang lain, Denton dan Woodward juga menjelaskan bahwa komunikasi politik juga berkaitan dengan tujuan komunikator yakni mempengaruhi lingkungan politik. Secara eksplisit, Denton dan Woodward menyampaikan bahwa faktor krusial yang membuat komunikasi bersifat politis ialah bukan sumber yang menyampaikan pesan namun konten pesan dan tujuan pembuatan pesan tersebut.

Sementara Stromback dan Kiousis (2011) mendeskripsikan PR Politik sebagai proses pengaturan atau pengelolan yang dilakukan oleh aktor politik, partai politik, atau lembaga-lembaga yang memiliki kepentingan secara politis atau bertujuan untuk mempengaruhi proses pengambilan kebijakan publik. Lebih jelasnya dipaparkan sebagai berikut,

Political public relations is the management process by which an organization or individual actor for political purposes, through purposeful communication and action, seeks to influence and to establish, build, and maintain beneficial relationship and reputation with its key publics to help support its mission and achieve goals.

Perbedaan yang signifikan di antara keduanya ialah bahwa komunikasi politik tidak membutuhkan adanya fungsi manajemen sebagai kegiatan dalam proses pengolahan komunikasi. Perbedaan lainnya ialah dalam politik, konsep kekuasaan (power) merupakan sumber daya langka yang diperebutkan sehingga melahirkan konflik. Dalam pendekatan PR Politik, konflik merupakan krisis yang pasti dapat diselesaikan dengan membangun relationship. Sekalipun memberi kesan naïf namun PR meyakini bahwa dialog akan membuahkan mutual understanding sehingga pada akhirnya akan terpenuhi mutual benefit.

\subsection{Pencitraan Kandidat Presiden Republik Indonesia dalam Pilpres 2014}

Dalam kontestasi politik, seorang kandidat harus memenangkan persepsi atau opini publik. Persepsi positif yang terbentuk di benak publik tentu lahir dari citra positif mengenai kandidat politik tersebut. Walter Lippmann (dalam Hallahan, 1999) mendeskripsikan citra sebagai "the picture's inside our heads" daripada "objective reality". Implikasinya ialah PR lebih berperan sebagai imagemaker atau spin doctor dalam mengonstruksikan realitas sosial.
Merujuk pada definisi PR Politik sebagai fungsi manajamen yang berorientasi pada tujuan politis maka citra kandidat politik menjadi sebuah keniscayaan dalam aktivitas PR Politik.

Citra kandidat yang menjadi preferensi konstituen pada umumnya merujuk pada dua hal yaitu peran politik kandidat (political role) dan gaya politik kandidat (stylistic role). Peran politik kandidat merupakan penilaian konstituen yang menyangkut kualifikasi yang dimiliki oleh kandidat dalam memenuhi ekspektasi publik terkait peran yang akan dimainkannya. Peran politik kandidat pada masa lalu, saat ini serta masa depan akan menjadi faktor penentu persepsi konstituen. Berbeda dengan stylistic role, yang sebenarnya tidak memiliki korelasi langsung secara politis namun memberi kontribusi dalam pembentukan citra kandidat. Stylistic role berkaitan dengan cara kandidat menampilkan dirinya sehingga memberikan kesan bagi konstituen. (Hacker, 1976). Dalam konteks inilah, peran PR Politik menjadi kunci bagi pengelolaan citra kandidat politik melalui perencanaan komunikasi yang strategis melalui media komunikasi PR serta agenda setting media.

Permasalahan akan menjadi kompleks apabila pemilik media masuk dalam pusaran kekuasaan sehingga mau atau tidak, isi media menjadi bagian dari konstruksi untuk memperluas pengaruh dan berperan sebagai image making machine. Di Indonesia, kepemilikkan media televisi misalnya, mayoritas berada di tangan aktor-aktor politik yang notabene memiliki kapital yang besar. Pemberitaan-pemberitaan yang diproduksi oleh media pun kemudian akan disesuaikan dengan 'taste' dan kepentingan pencitraan dari sang pemiliknya. (Indrayani, 2009)

Kontestasi pemilihan presiden RI 2014 lalu merupakan empirik mengenai otentisitas aktor politik di Indonesia yang secara keilmuan signifikan dan berkontribusi pada PR Politik di Indonesia. Sebagai dua kandidat yang bersaing, Prabowo dan Joko Widodo memiliki pendekatan PR yang berbeda dalam mengelola pesan baik melalui media berbayar atau iklan maupun tidak berbayar. Prabowo dalam beberapa tayangan iklan lebih menampilkan sosok militer daripada pemimpin yang dekat dengan rakyat. Isi pesan yang disampaikan juga lebih bersifat propagandis daripada lawan politiknya yang menekankan komunikasi blusukan. Citra Prabowo sangat militeristik serta otokratis, berbanding terbalik dengan Jokowi yang mengumandangkan konsep "kita" dalam beberapa iklan politiknya. Konsep kita ini mendekatkan kandidat politik dengan konstituen, 
memberi kesan two way symmetrical communication. Pilpres 2014 lalu juga menunjukkan adanya partisipasi politik yang massif di segala lini baik ranah media sosial, media massa, diskusi publik maupun interaksi komunitas lainnya. Pembangunan serta pemberdayaan komunitas berbasis social media merupakan viral communication yang strategis untuk menggalang suara dan loyalitas. "I stand on the right side" sebagai jargon konstituen adalah bentuk kebanggaan partisipasi publik yang notabene pada era sebelumnya lebih didominasi oleh euphoria golput. Desas-desus mengenai kerusuhan dalam pelantikan Joko Widodo sebagai presiden 2014-2019 juga menjadi luntur ketika presiden terpilih melakukan kunjungan kepada lawan politiknya sehingga menjawab keresahan dan pertanyaan di level akar rumput mengenai kemungkinan terjadinya konflik politik. Dalam hal ini, upaya preventif telah dilakukan melalui engagement dan relationship. Presiden sebagai aktor politik yang terlegitimasi merupakan sumber yang memiliki kredibilitas dan power untuk mengiring opini bahwa semua stakeholder serta publik berada dalam situasi yang mutual understanding.

\section{KESIMPULAN}

PR Politik merupakan salah satu kajian dalam PR yang sekalipun dipandang baru namun secara praktis telah ditemukan bahkan sebelum ilmu politik didefinisikan. Sekalipun, menjadi bagian dalam anatomi PR namun PR Politik menjadi semakin teridentifikasi menjadi salah satu bagian unik dalam tubuh PR yang berkaitan dengan political domain. Sebagai sebuah kajian yang relatif baru, PR Politik juga beririsan dengan komunikasi politik. Kata kunci pembeda diantara keduanya ialah terletak pada relationship dan management function.
Gelombang demokratisasi khususnya di negaranegara berkembang dan dunia ketiga, menempatkan opini publik sebagai faktor pembentuk citra kandidat yang pada akhirnya menentukan suara serta pilihan konstituen. Kondisi ini semakin menguatkan posisi PR Politik sebagai sebuah studi yang memiliki relevansi dalam menjelaskan fenomena politik dengan sudut pandang PR.

\section{DAFTAR REFERENSI}

Bernays, E. L. (2003). Manipulating Public Opinion: The Why and The How. American Journal of Sociology. 33(6). 960-961.

Esser, F. (2008). Spin Doctor. Victoria: Blackwell Publishing.

Hacker, K. (1976). Candidate and Their Images, dalam http://campus.murraystate.edu/faculty/mark.watt ier/cimages3.PDF

Hallahan, K. (1999). Seven Models of Framing: Implications for Public Relations. Journal of Public Relations Research, 11(3), 205-242.

Heryanto, G. G \& Rumaru, S. (2013). Komunikasi Politik: Sebuah Pengantar. Bogor: Ghalia Indonesia.

Indrayani, I. I. (2009). Media dan Politik Citra Dalam Politik Indonesia Kontemporer, Scriptura, 3(2). 137.

McNair, B. (2011). An Introduction of Political Communication. New York: Routledge.

Moloney, K. (2000). Rethinking PR: The Spin and The Substance. New York: Rouledge.

Stromback, J \& Kiousis, S. (2011), Political Public Relations: Principles and Applications. New York: Routledge.

Strömbäck, J \& Kiousis, S. (2013). Political Public Relations: Old Practice, New Theory-Building. Public Relations Journal, 7(4), 2-6.

Wasesa, S. A \& Macnamara, J. (2013). Strategi Public Relations. Jakarta: Kompas Gramedia. 